\title{
MODEL OF LAISSEZ-FAIRE AND TRADITIONAL EDUCATION IN THE FAMILY AND SCHOOL
}

\begin{abstract}
Raising a child in the family and educational institutions causes a lot of problems and difficulties. This is due to the crisis of the contemporary Polish family, laissez-faire, dynamic socio-economic and cultural transformations and technopolisation of life. Growing up in the new reality and the education of an individual requires the efficient interaction of all "community" environments, aimed at shaping a comprehensive and harmonious personality and empowerment.
\end{abstract}

Keywords: child, education, laissez-faire, family, institutional centres, transformation, impacts, threats.

\section{Introduction}

We operate in the era of modernity, in which the dynamics of socio-political and economic transformations and extremely fast-paced technopolisation of life influence the process of raising a child from an early age. The social environment, in which a child resides, is a constitutive chapter in her harmonious or disharmonious development. The modern Polish family is currently undergoing a serious crisis, in which education at home and other institutional centres of education causes a lot of problems and difficulties. Parents are thus faced with a dilemma on how to raise a child? Are the traditional methods based on prominent figures, norms, patterns, ideals more effective than those permissive, liberal, laissez-faire, stressfree methods associated with exceptional freedom, ease, fulfilling typical desires, lack of control, joint discussions, negotiations, problem solving? In this article I will focus on the model of laissez-faire education, which increasingly penetrates the margins of everyday life of Polish families where children are not limited by anything and, most importantly, parents, teachers, caregivers are often deprived of 
authority. However, it does not mean that I will skip the earlier traditional model of raising a child.

\section{Laissez-faire and its assumptions}

The source of laissez-faire are philosophical views advocating individual freedom, especially in the socio-economic dimension. Laissez-faire concerning the upbringing of the child refers to the formation of typical attitudes, consisting of leaving him/ her complete freedom of action. It is connected first of all with extreme tolerance towards all news and changes, and with the conviction that human development should not be interfered with. Due to the fact that in contemporary families usually material possessions, education, intelligence and resourcefulness are the things that matter - the typical easy lifestyle of children is increasingly visible in the everyday situations of their functioning. Laissez-faire is recognised as stress-free, without limitations, fines, bans, without teaching standards and rules; there are only minimal requirements and expectations. As a "different" way of education of the individual, it came to us from the United States, and his representative was B. Spock, a supporter of typical, free education of the child in the development of its activity. According to him, the child's natural desire to explore the world may be inhibited if parents, caregivers and educators impose their peculiar style of education, guide his/her activity, use the commands and prohibitions, assuming dominant and imperious methods. According to Spock (1992, p. 23) we should leave a child a lot of flexibility in terms of its multilateral activities. Much more valuable is the freedom and spontaneity of the individual rather than restriction, absolutism, principality. The author prefers autonomy in taking action related to the needs and interests of pupils rather than cognitive routine and servitude in close planning. Thanks to free education, individuals are learning to live with others, to cooperate, to be responsible, to think independently; they are learning self-discipline, entering into mutual interaction, developing management skills. E. H. Erikson (2000) in his empirical research, drew attention to the disadvantage of imposing authority by parents, with their opinions and behavioural patterns. This association was observed when examining relationships that widely affect the child in the various stages of its development. Permitting him/her to be self-reliant in actions, will, in time, lead to a situation in which it comes to that, that there are several ways to solve the same problem; he/she will show a strong will and develop self-esteem. Laissez-faire as a kind or type of education leads to absolute freedom infantilism, bears the hallmarks of the syndrome "playful Dyzio". Manifestations of such freedom, according to M. Czerepaniak-Walczak (1994, p. 106) are characterised by the search for experience, for which the child does not take any responsibility (destructiveness, stimulants, intoxication, dizziness, use of the Internet, awareness of having "many lives" etc.). Impunity and lack of any rules lead to enslavement and unlimited consumption (Barber, 2008). Children meet their needs without looking 
at the costs and effects that result from their activities. Freedom associated with the experience can take on the character of being a threat to others, hooliganism, crime, aggression, violence, triggering temptations, fostering impunity, in short killing a sense of responsibility for own actions.

\section{Family as a basic environment in child education}

The family is the first and most important environment of education of the child. In the pedagogical literature it is referred to as a community of people and the general human institution, encountered in all ages and cultures. It constitutes a fundamental form of human coexistence and integral part of every society. It has an institutional character. It is based on marriage or partnership, it is a legal entity (Dyszewski 2000, p. 23). The concept of family is recognised as interdisciplinary. It is the object of educational, sociological, psychological, medical, economic and legal research and is the closest social environment of a child. Its socio-cultural dimension creates a basis for shaping a plenipotentiary role of the individual. As an open, intimate group, a cradle of personality development, it meets certain objectives, tasks and functions. Family, apart from meeting the basic needs of the child, should be his/her personal model, educational ideal, should take care of the comprehensive personality development and introduce multi-directional communication. As the basic social cell, it has to create an atmosphere for the proper education, love, stimulation of development, health, education. It should demonstrate: flexibility, responsibility, introduction to dialogue as well as setting limits. In the context of the child's upbringing in the family, we should pay attention to the modern types of family, parental attitudes, styles and educational methods. L. Starowicz (1999) proposes an innovatively developed classification of types of families (Table 1 ). 
Table 1. Typology of family

\begin{tabular}{|l|l|l|}
\hline Type of family & \multicolumn{1}{|c|}{ Father } & \multicolumn{1}{c|}{ Mother } \\
\hline $\begin{array}{l}\text { "Mamizm" } \\
\text { - the cult of } \\
\text { mother }\end{array}$ & $\begin{array}{l}\text { Subordinate, submis- } \\
\text { sive, reduced to the role } \\
\text { of an "echo" of mother, } \\
\text { excluded from actions } \\
\text { and making important } \\
\text { decisions, executing } \\
\text { commands. }\end{array}$ & $\begin{array}{l}\text { Full of energy, the dominant, } \\
\text { priority, a strong personal pat- } \\
\text { tern, creates a style of everyday } \\
\text { living of family members, makes } \\
\text { the division of roles, attitudes } \\
\text { towards each other, sex, regulates } \\
\text { social attitudes, defines what is } \\
\text { most important for the family in } \\
\text { the upbringing of children, the } \\
\text { division of the budget, spend- } \\
\text { ing free time. Identification of } \\
\text { the role of the female - daughter. } \\
\text { Preparing sons for the transition } \\
\text { into the care of a future partner. } \\
\text { The primacy of women's concept } \\
\text { of life, the transition to the next } \\
\text { generation (daughter). Sons are } \\
\text { passive, effeminate, helpless. }\end{array}$ \\
\hline $\begin{array}{l}\text { Autocratic } \\
\text { fathers }\end{array}$ & $\begin{array}{l}\text { Head of the family, the } \\
\text { judge, the prosecutor, } \\
\text { the personification } \\
\text { of power, norms and } \\
\text { obligations, the great } \\
\text { authority, breadwinner. }\end{array}$ & $\begin{array}{l}\text { Immature, very respon- } \\
\text { sible, low authority, lack of } \\
\text { decision-making. }\end{array}$ \\
\hline "Buddy" family of a family & \multicolumn{3}{|c|}{$\begin{array}{l}\text { Characteristics of a family } \\
\text { "Nuclear" family }\end{array}$} & $\begin{array}{l}\text { Lives its own life, unity and cooperation } \\
\text { difficult to achieve, outdoor relationships } \\
\text { dominate (social, professional, friendly } \\
\text { with others), the need for emotional bond } \\
\text { met outside the home, children neglected } \\
\text { emotionally and spiritually; they feel to- } \\
\text { ward their parents emotional coldness and } \\
\text { distance, Western countries, Poland }\end{array}$ \\
\hline & $\begin{array}{l}\text { Comradeship, frontier of infantilism, lack } \\
\text { of age barriers, position, authority, col- } \\
\text { legial relationships with parents, lack of } \\
\text { standards, policies, a small difference in } \\
\text { age between parents and children (parents } \\
\text { unprepared for parental roles), partner- } \\
\text { ships, reduced sense of responsibility. }\end{array}$ \\
\hline
\end{tabular}




\begin{tabular}{|l|l|}
\hline "King Matt" family & $\begin{array}{l}\text { Focused on the child (the central figure, } \\
\text { the most important), subordinate to sa- } \\
\text { tisfying the desires, removing difficulties } \\
\text { and obstacles; serving the child, the reali- } \\
\text { sation of child's needs, making life easier, } \\
\text { the release from duties, self-centeredness; } \\
\text { catchword: "take over give", laissez-fair. }\end{array}$ \\
\hline Family emotionally labile & $\begin{array}{l}\text { Immature, infantile personalities, trans- } \\
\text { ition of own emotional instability on } \\
\text { children, mood swings, neurotic attitudes, } \\
\text { immature personality, radically changing } \\
\text { emotional ties, conflicts resolved irratio- } \\
\text { nally, formation of subgroups and camps. }\end{array}$ \\
\hline Family with myths & $\begin{array}{l}\text { Staying by one of the parents outside the } \\
\text { circle of family life, the other person is } \\
\text { building for their own use and children's, } \\
\text { myths about this person. }\end{array}$ \\
\hline Family with alliances & $\begin{array}{l}\text { Formation of overt or covert alliances in } \\
\text { emotional relationships (e.g. Mother with } \\
\text { her daughters against the father, the father } \\
\text { and the children against the mother, the } \\
\text { children against the father, etc.). }\end{array}$ \\
\hline Partner family & $\begin{array}{l}\text { Collaboration, cooperation of parents, } \\
\text { democratic roles and responsibilities, the } \\
\text { authority of parents - the maturity of per- } \\
\text { sonality, competent educational activities - } \\
\text { consciously planned, controlled formation } \\
\text { of mature and responsible personalities of } \\
\text { children. Western - societal transforma- } \\
\text { tions, getting to know the accuracy of fa- } \\
\text { mily life, co-educational education system. }\end{array}$ \\
\hline
\end{tabular}

Source: own elaboration.

The above typology can be customised to the right kind of education: traditional or laissez-faire. All of these types of families create a specific family atmosphere, preference for specific attitudes, styles of education and the principles and methods of education. The attitude of the parents, therefore, influence the personality development of the child and its components: the attitudes, needs, behaviour, standards, policies, temperament, cognitive abilities, interests, beliefs and spheres: physical, mental, social - emotional, motivational. Their harmony is a determinant of the flexible operation of the parents towards the child and adoption by them of the right attitudes. In turn, these inappropriate, inter alia, aggressive, excessive, meticulous, 
anxious and compensatory attitudes of the mother and rigorous, strict and serious attitudes of the father become a frequent cause of pathological behaviour of the child and behavioural disorders manifested in egocentricity, lack of sense of reality, initiatives, lower value and a lack of interest in their own activity. Modern families, especially those that are "busy", do not spend time on education, they meet only the material needs of the child, trying to give him/her a better start in later life. They forget about the most important, emotional and spiritual needs. Parents are the first teachers and the guardians of the child. They have a special emotional bond with their baby. Each family has therefore their characteristic style of the inner life, which includes education and the teaching of children (Kawula et al., p. 2004). The educational functions performed by the family are implemented in different ways, and parenting style (authoritative, democratic, liberal) determine the quality and quantity of impacts on the psyche of the child. The style is a reflection of educational methods, dependent on who directs a particular family. In the case of laissez-faire, we have to deal with the liberal style, free of consequences. It is characterised by the way of impact on the child, occasionally and accidentally, but also systematically and deliberately planned. It provides maximum freedom in his/her actions. Interference occurs when norms of behaviour are drastically violated. Parents do not restrict or punish, they justify the behaviour of the child in every situation. The socialization process is delayed, as well as shaping social attitudes and moral standards, self-centeredness is developed and difficulties in adapting to the smooth functioning of the peer group arise. Features of those pupils are the following: immature behaviour, low self-control, timidity, impulsiveness, as well as continuous complaints and grievances to the guardians. Methods are a fundamental element of education as they integrate with the objectives, creating the style and atmosphere of education. They are used consciously in the course of systematic and repeated actions of parents. M. Grochociński (1986, p. 26) proposes a classification of methods of upbringing in the family because of the direct or indirect influence of parents on their children, emphasising the priority of immediacy of contact of parents with a child. The main condition for the effectiveness of these methods is the authority and confidence of parents, the power of positivity of emotional bonds, free, sincere and friendly atmosphere in the family. It is accompanied by: explaining, convincing, suggestion, persuasion, rewards and punishments, identification with attitudes of literary characters, historical heroes seen in films and with people living today, the methods of passive and active listening, conflict resolution, supporting the activities of the child, active and creative leisure time and the nurturing of family tradition. The educational impacts based on the methods of indirect effects depend on the organisation of the conditions and ways of life of a child in such a way, that its experiences, reactions, behaviour bring him/her closer to what constitutes educational objectives and contributes to the harmonious development of his/her personality. These methods include the organisation of the educational environment, including: order in family life, the activation of 
the child, stimulation to activities in the peer group. The author believes that the most important methods of upbringing in the family are: reward and punishment, organising conditions for education, rational care, consistent behaviour and rational requirements, own example and showing the educational patterns. In everyday life, parents use many kinds of methods of education. Thanks to the diversity and strength of educational influences they aim at the acquisition of skills and shaping attitudes and habits in relation to the child. Parents often use the method of direct influence: conversation, explanation, rewards and punishments. It is less likely for them to use the methods of indirect impact through the creation of appropriate educational situations and the organisation of the environment. They also do not organise in a rational and thoughtful way free time for children, do not control the hours spent at the computer and watching TV (Kułaczkowski 2009, p. 81). The methods selected should be adapted to the capabilities of the child, referring to his/her experience, taking into account, above all, his/her personality traits. An individual approach to every situation of education should be most important while maintaining empathy, kindness and tolerance.

\section{The school as an educational environment of the child}

The second educational environment of the child after the family is the school. It is where a child shapes a versatile personality. School education, according to T. Gordon (2009, p. 116) is understood as a wise accompaniment to the student in his/her development. The school bears the responsibility for the level of education of a child, who gradually learns who he is and shapes the image of himself. In the course of school education, he develops cognitive abilities and interests. The school develops a specific identity and teaches to accept oneself. The task of the school is primarily a child's upbringing in a deliberate and intentional manner, consistent with the axiology of values, choices, inculcated norms, shaping socialmoral attitudes. It is important that the norms of behaviour inculcated in school are respected and implemented in a family environment.

In the era of political, economic and social transformations, contemporary school begins to lose its status. It becomes the cradle of the growth of negative social behaviours and the laissez-faire forms of education are reflected in the course of daily contact between teachers and students. In the institutional facilities, local communities, the number of aggressive individuals is getting bigger, accompanied by the broadly understood crisis of bonds and peer relationships. The loss of authority and lack of trust in adults is very visible. There has been a lack of clarity and complexity of the implemented concepts of education. It is difficult to determine its scope and its implementation in the school. Common behavioural problems are very difficult to solve. We observe destructive factors at schools, which influence the behaviour of children and adolescents. These include: the lack of a personal, subjective approach to student attitudes in the class or group and its global success, 
lack of knowledge and skills and the willingness of teachers to explore and search for information about the social context; lack of understanding, help, support, skipping of moral problems, escaping from educational activities, lack of personal patterns of relating to other people, not taking into account the characteristics of kindness, justice, love, honesty. The partnership principle of education should be systematically implemented in a child's education environments. It appertains to the community of mutual interaction of three educational entities, relationships, mutual dialogue, interaction, negotiation, solidarity, interpersonal externalization, educational and socio - cultural activity, psycho-cultural approach to education, teaching, learning as an interactive processes. This rule applies to students, teachers and parents, it is based on multilateral relations, equality, support and accountability. In addition to pursuing a common objective, voluntary participation, defining the responsibilities, space for mutual, multi-directional communication, other important concepts are: kindness, empathy, altruism, willingness to support and involvement in school activities for a harmonious development of the student. The principle also requires determining the delineation of certain rules, areas and framework of a broad cooperation, which are much missing in the daily educational process.

\section{Raising a child as a difficult challenge in the era of modernity}

In a typical Polish family there are conflicts, problems, difficulties with which parents are unable to cope, becoming helpless in many situations. On the surface, they seem trivial, but for the children they are important. They refer to things, often not important in the opinion of adults such as: choice of friends, style of dress, progress at school, leisure, etc. For the youngest, these values are considered to be permanent and not undergoing any change (Dabrowska 2001, p. 48). They are not willing to compromise in terms of specific ideas about values and beliefs. Similarly, parents oppose the children's behaviour by not accepting their actions. They do not tolerate resistance, they believe that their views on upbringing are unique and very right, they reach for the attributes of power, use inappropriate educational methods such as fines and bans, destroying the correct family bonds, breaking mutual dialogue, and their overbearing and unilateral, transmission monologue is reflected often in a lack of acceptance, hatred, anger and lack of mutual understanding. The family crisis is growing. Instead of showing a child the right way of behaviour, teaching altruism, transmitting axiological values, being a role model, parents tend to show emotional coldness, demand complete obedience and absolute adaptation, they do not explain commands that they systematically impose and require their absolute implementation, they punish for contempt, use the method "children do not have a voice". Individuals that grow up in the type of family that uses typically authoritarian parenting style are usually reliant, self-contained, constantly dissatisfied, disinterested in exploring the world, demotivated to gain 
achievements and successes, have low self-esteem, become suspicious and envious. In the social environment we observe the problems and conflicts between the child and his mother and father, between siblings, peers, teachers and students and parents etc. There are winners and losers. Winners strongly emphasize their power and authority, rights, prohibitions, restrictions, decide against the will of others not taking into account any compromise. Losers, in turn, approve freedom, avoid restrictions, indicate the dominance of the opposite side, meet wishes, do not deny anything, accept the typical assumptions of laissez-faire education. The loser experiences wrath and anger towards the victor. Both methods, as T. Gordon (2009, pp. $167,218)$ mentions, include a power struggle, the opponents do not hesitate to use force if they believe that it is necessary to win. In both cases there is a blockage in communication that involves: mutual accusations, blaming, moralizing, warning, adopting the attitude of a martyr, sarcasm, prophecy, ridicule, embarrassment, consolation, interpretation, diagnosis, questioning, ignoring the content of the message, giving orders. The author negates parental responsibilities in the upbringing of the child and their widely expanded authority. Parents do not properly interpret the significance of authority and its impact on the child. In traditional education they have a psychological advantage over a child. Children, in turn, assign parents a lot of features, which in fact they do not have, i.e. for a small child "his mother knows best". They use their power. This type of tightened educational impacts make children become anxious, neurotic, hostile and distrustful of others. Parental power status fades with the age of a growing up child, for whom the peer groups become priority. During this period, he/she becomes self-contained, and the system of penalties and orders is usually no longer useful. The circle of friends, school, sport, own plans and successes becomes central. A growing up child tries to avoid the penalties imposed by parents, ignores prohibitions, does not follow established standards. They often take rebellious attitudes, imperiousness and even aggression. In the process of raising a child, the family and other institutional centres should proceed carefully, without inhibitions and disappointments, avoiding common mistakes in educating. Parents and teachers often evaluate their impact in terms of educational success or failure. I believe that a substantial form is a cross between the two, based on the pedagogy of reciprocity, shaping the local community understood as a network of social interactions and ties, created in the process enabling the achievement of common values, symbols, traditions, and at the same time using awareness, individuality and the desire for cooperation. This type of idea should be accounted for as a specific way of organising relations. Instead of the traditional model, broadly understood socialization is used, specifying the scope of mutual responsibility and ensuring coherence, in order to seek new, better and common parenting. Of primary importance is the involvement of three entities in a child's education. This triple subjectivity consists of creative and dynamic support of the development of students through the involvement of teachers, parents and the local community in the course of the process of raising children. Above all, 
it is important for multilateral development, for further success and preparation for interactive participation in social life, being essential for the further biography. Being included in the dialogue and mutual problem and conflict resolution teaches children self-reliance, autonomy and empowerment. Talking with them, identifying the problem and specific feelings and expectations regarding the situation of education, avoiding tasks humiliating or blaming them, showing faith in the reliability of the intentions of parents, teachers, the possibilities of solving the problem, evaluation of proposed solutions, decision-making, its performance and critical approach to the situation are the way to achieve educational success. A child comes into contact with others in a democratic, open way, recognises the needs of others, considers them, tries to make choices through their own experience.

\section{Conclusion}

Raising a child in contemporary times, in the era of industrial changes, when we depart from the collective mentality and progress to the individualistic mentality, puts pupils, teachers and parents facing new challenges and tasks, which create numerous problems that are very difficult to solve. The modern model of education towards rationalisation and secularisation of life involves negligible sacredness of marriage, religious dissatisfaction, increasing number of divorces, pathology, cohabitants, open homosexual relationships, single parenthood, all threatening the harmonious functioning of the child. It requires conscious and intentional educational activities whose goal is to achieve a relatively stable, favourable change in the child's personality. These actions need to take into account the holistic development and rationally planned educational situation, consisting of conditions, circumstances and incentives. The element of education is the living environment of the child, characterised by the kind of specificity of interaction favourable or unfavourable to its development. Changing the model of a family from a large, multigenerational one, into small, usually one-child families, broken families, mixed families, multicultural, not legalised families and the lack of a clearly defined concept of education in Polish schools (traditional, or laissez-faire), euroorphanhood education in the border region, the lack of authorities, relativism of values, selective treatment of values, numerous threats of civilisation, reducing the alcohol, nicotine, drugs, sexual initiation age, auto-pornography and prostitution of girls, promotion of lifestyles based on an easy happiness, loss of the education through work, physical attractiveness, the era of mobiles, tablets, smartphones, uncontrolled internet, laptops, computer games, messiness of speech, praise and speaking by children and young people, misspellings, aversion to reading books are the basis for pedagogical discourse on the effectiveness of education of the young generation. The contemporary Polish family is a family of television and computer. In educational practice, we encounter liberalisation of behaviour of pupils, extraordinary freedom of action, aggression and violence against each other 
and adults. How are we supposed to speak about the effectiveness of education surrounded by still growing threats? How should we achieve it, what action should be taken? Or should we use edifying conversation, "mould" the pupils according to strict predetermined, behavioural patterns, rewards and punishments, to present the truth about the moral values that the parents recognise and try to give to the child, consciously realising this truth, but without the support of the family home, raised in a triangle: pupil-teacher-goal, without difficulties and setbacks. I have been asking myself this question for several years: how to educate: stress less and use traditional methods? To this day I cannot find an answer. Laissez-faire is a system of civilization of death, a dead-end of a post-modernity, it can be regarded as a salvation or a curse, can be regarded as an utopia. To raise with no stress, in my understanding, is to create an individual who is spoiled, mannered, devoid of any principles, a child who can do whatever he/she wants. In turn, educating traditionally, "training", using domineering trainings, punishing, enslaving, planning and arranging everything - we are still not able to achieve positive educational effects. Therefore, none of these positions will prepare the pupil for an independent, accredited, mature and fully-fledged functioning in later life. In my opinion, further, still unexplained reflections on the ways of educating and upbringing are still open and are waiting for constructive and effective solutions.

\section{Bibliography}

Barber B. (2008). Consumed. How the market corrupts children. Warsaw: Publishing House Muza.

Czerepaniak-Walczak M. (1994). Between adaptation and change. Szczecin: Publishing House of the University of Szczecin.

Dąbrowska J. (2005). Understanding child. Warsaw: Educational Publishers PARPA.

Erikson E. (2000). Childhood and society. Poznan: Publishing House REBIS.

Gordon T. (2009). Education without failures. Warsaw: Publishing House PAX. Grochociński M. (1986). Pedagogical culture of parents. [In]: Family and child, ed. M. Ziemska. Warsaw: PWN.

Kawula S., Brągiel J., Janke A. (2004). Pedagogy of the family. Areas and panorama of the issues. Toruń: Publishing Adam Marszałek.

Kułaczkowski J. (ed.) (2009). Selected research areas of pedagogy family. Warsaw: Publishing and Printing Diocese of Rzeszow.

Spock B. (1992). About parenting. Warsaw: PZWL.

Starowicz L.Z. (1999). Encyclopedic Dictionary. Love and sex. Warsaw: Publishing EUROPA. 


\section{WYCHOWANIE LESEFERYSTYCZNE I TRADYCYJNE W RODZINIE I SZKOLE}

Streszczenie: Wychowanie dziecka w rodzinie i placówkach instytucjonalnych sprawia wiele problemów i trudności. Jest to spowodowane kryzysem współczesnej rodziny polskiej, leseferyzmem, dynamicznymi przeobrażeniami społeczno-ekonomicznymi i kulturowymi oraz technopolizacją życia. Dorastanie jednostki w nowych realiach i jej wychowanie wymaga efektywniejszych oddziaływań wszystkich „wspólnotowych” środowisk, mających na celu kształtowanie wszechstronnej i harmonijnej jej osobowości oraz pełnomocności.

Słowa kluczowe: dziecko, wychowanie, leseferyzm, rodzina, placówki instytucjonalne, przeobrażenia, oddziaływania, zagrożenia.

Jolanta Karbowniczek - doktor habilitowana nauk społecznych w zakresie pedagogiki, profesor Akademii Ignatianum w Krakowie, zatrudniona na Wydziale Pedagogicznym, w Instytucie Nauk o Wychowaniu, kierownik Katedry Dydaktyki i Wczesnej Edukacji Dziecka. Adres do korespondencji: ul. Kopernika 26, 31-501 Kraków. Adres e-mailowy: jkarbow@poczta.onet.pl. 